\title{
$\begin{array}{lllllllllllllllll}\mathbf{A} & \mathbf{R} & \mathbf{T} & \mathbf{Y} & \mathbf{K} & \mathbf{U} & \mathbf{L} & \mathbf{Y} & / & \mathbf{A} & \mathbf{R} & \mathbf{T} & \mathbf{I} & \mathbf{C} & \mathbf{L} & \mathbf{E} & \mathbf{S}\end{array}$ \\ ROCZNIKI KULTUROZNAWCZE \\ Tom/Vol. XI, numer/number $3-2020$ \\ DOI: http://dx.doi.org/10.18290/rkult20113-3
}

\section{CAMERON GORDON}

\section{COVID-19 AND THE FUTURE \\ OF WESTERN CIVILISATION}

\section{INTRODUCTION}

"No man is an island", John Donne wrote centuries ago. The current Covid-19 pandemic makes this idea more relevant than ever (though a more poetical name than "coronavirus" is probably warranted). Two other lines from Donne's poem are even more apt: “Any man's death diminishes me, / Because I am involved in all mankind".

Gender-biased language aside, the sentiment is a good starting point for a discussion of how the current disease epoch will likely shape the continued course of Western civilisation. Civilisation is in many ways the apotheosis of the human social impulse, good and bad, and, whatever happens, the Age of Coronavirus is going to shape the western version of this shared culture profoundly, if not perhaps even derail it entirely. The question is how.

\section{THE SOCIALITY OF DISEASE}

Disease has obviously have been around for a long time. All mammals carry elemental bacteria (e.g. staphylococci, streptococci, and coliform bacteria) as part of normal physiological functioning such as digestion. It is

CAMERon Gordon, PhD - College of Business and Economics Australian National University (ANU), Canberra; e-mail: cameron.gordon@anu.edu.au. ORCID: https://orcid.org/00000003-0434-978X .

${ }^{1}$ John Donne, Devotions upon Emergent Occasions, no. 17. Originally published in 1624. Bartleby.com - Great Books Online, accessed 1 August, 2020, https://www.bartleby.com/73/ 134.html. 
believed that infectious disease in humans emerged from these bacilli in ancestors of the Homo line around 2 million years ago. ${ }^{2}$

Imbalances and disturbances of these processes still cause certain kinds of disease, showing that epidemiologically no human being is an island, even within themselves. Human beings are deeply social animals and this "sociality," to use the ethological term, has consequences, one of them being increased susceptibility to communicable disease. The simple herd instinct increases the probability of disease transmission between humans. As social organisation advances so does disease. ${ }^{3}$

Movement from small nomadic hunter gatherer tribes to semi-fixed agrarian settlements are thought to have been a major ecological shift in the human-microbe relationship in several ways. First, the development of agriculture created close and ongoing contact between humans and animals, leading to transmission of infectious agents from one species to another, a process referred to as "zoonosis." In this way some animal diseases became endemic in humans, while new hybrid diseases were created after interaction with the human genome. Second, increasingly dense and fixed settlement allowed for the proliferation of "pest" species such as rodents and mosquitoes that lived off humans ("commensal" in technical jargon) that increased the variety and efficiency of zoonosis. Third, as the scale and scope of human density grew, so did what epidemiologists refer to as the "crowd" diseases, like measles and influenza. ${ }^{4}$

This, however, was only the beginning. For humanity is not only a socialising species but a civilising one. Civilisation is a grand term, not easily defined. Some consider it a form of culture writ large, the usage that the political scientist Samuel Huntington seems to use in arguing for a modernday "Clash of Civilisations." Other definitions are more subtle. Norbert Elias's model is probably one of the most elaborated, and particularly useful for the present discussion. ${ }^{6}$

Put extremely briefly, Elias refers to a "civilising process" that starts with a natural "ambivalence of interests" between human beings in society in

\footnotetext{
${ }^{2}$ Ethne Barnes, Diseases and Human Evolution (Albuquerque: University of New Mexico Press, 2005).

${ }^{3}$ Arno Karlen, Plague's Progress: A Social History of Disease (London: Gollancz, 1995).

${ }^{4}$ E. Fuller Torrey and Robert H. Yolken. Beasts of the Earth: Animals, Humans and Disease (New Brunswick, NJ: Rutgers University Press, 2005).

${ }^{5}$ Samuel Huntington, “The Clash of Civilizations?” Foreign Affairs, 72, no. 3 (Summer, 1993): $22-49$.

${ }^{6}$ Norbert Elias, The Civilizing Process. Sociogenetic and Psychogenetic Investigations. Revised edition (Oxford: Blackwell, 2000).
} 
which groups simultaneously display enmity towards one another along with a mutual interdependence on each other. This ambivalence grows as societies evolve beyond thin webs of largely autarkic groups. "Permanent observation" in simpler societies evolved into "attunement" as social networks grew in complexity, requiring constant social balancing, a social division of labour, and growing inner restraint and self-regulation that became "second nature" or "habitus," to use Elias's term. The instinctual "animal" in the human thus became increasingly suppressed in the interests of social peace and order.

Thus Elias posits "sociogenesis" and "psychogenesis." The former refers to changes in social structure which occurs at a collective, social level. The latter refers to changes in the individual psyche, which takes place within each individual. Changes in one affect the other, with causality running in both directions in a constant evolution.

The payoff to this process is the modern world and its civilisation: a social/individual collective that can produce great art, highly productive cities, philosophical systems, relatively pacific social norms, the modern state, and civil society. To this can be added the current multilateral global order with its high degree of economic output. But there are obvious costs as well, including a rising ferocity of periodic collective violence exercised through the State, a psychic numbing arising from an increasingly abstract relationship between individuals and society, and voracious and unsustainable exploitation of resources.

Elias himself was agnostic about the "goodness" or "badness" of human civilisation, seeing it like any other socialisation process, a natural human imperative than can lift humans higher or lower depending on unique and dynamic historical circumstances. This contrasts with Freud's view, expressed in his seminal work, "Civilisation and its Discontents." "Freud combines the Enlightenment view of the fundamentally rational human being with his own theory of an unconscious driven by animal instincts that need to be properly channelled for the good of society, a conflict between two antagonistic and yet basically immutable human characteristics. As will be shown later, this view has penetrated some of the current view of the Covid crisis.

\footnotetext{
${ }^{7}$ Sigmund Freud, Civilization and Its Discontents, trans. James Strachey (Peterborough: Broadview Press, 2015).
} 


\section{THE HUMAN ANIMAL, ENVIRONMENT, SOCIETY, AND PANDEMIC}

Like other large mammals, humans are instinctually predisposed to physically alter the environment in which they live. This disruptive species trait is the source of both human historical progress but also profound changes in the ecology and occurrence of infectious diseases. Microbiologist Rene Dubos posits human history as consisting of a series of major transitions in the relationship between the human and microbial worlds, with zoonosis being the major causal factor. ${ }^{8}$ It is widely recognised that the current Covid pandemic is only the latest disease outbreak that has its roots in profound human disruptions of animal biomes through relentless economic development, residential settlement and resource extraction in "wild" areas, and the human-induced climate change that has gone along with it.

Even in a basic biological sense human disease is not a passive part of some immutable natural order within which humanity sits, but a product of a constantly evolving holistic interaction. This is especially true of epidemics and pandemics, where war, conflict, territorial expansion, and the institutions, infrastructure and population densities that simultaneously support and cause such things are their major progenitors. All these things, in turn, are products of the civilising imperative. As civilisation advances, epidemic and pandemic do too. (A terminological note: "epidemic" is defined in the authoritative Dictionary of Epidemiology as "the occurrence in a community or region of cases of an illness...clearly in excess of normal expectancy." "Pandemic" is simply an epidemic with especially large, though not precisely defined, spread across space and population). ${ }^{9}$

It is perhaps no surprise that once human beings began to record their history, their accounts were shot through with plagues of various sorts. The Old Testament records numerous epidemics, such as one in Egypt occurring late in the Middle Kingdom, that causes "sores that break into pustules on man and beast." Deuteronomy reports that the Hittites suffered from twenty years of pestilence following their capture, importation, and enslavement of Egyptians as prisoners-of-war. One of the Four Horsemen of the Apocalypse referred to in the New Testament's Book of Revelations is Pestilence. ${ }^{10}$ The

\footnotetext{
${ }^{8}$ René Jules Dubos, Mirage of Health: Utopias, Progress and Biological Change Rutgers University Press, 1987.

${ }^{9}$ Miquel Porta (ed.), A Dictionary of Epidemiology (5 $5^{\text {th }}$ edition) (Oxford: Oxford University Press, 2009).

${ }^{10}$ Anthony J. McMichael, "Environmental and Social Influences on Emerging Infectious
} 
Iliad contains a description of an epidemic occurring around $1250 \mathrm{BCE}$ while the Greek historian Hippocrates describes numerous outbreaks of diseases such as mumps. Thucydides recounts the Plague of Athens (430-426 $\mathrm{BCE}$ ), occurring during the Peloponnesian Wars. ${ }^{11}$

These episodes certainly constituted epidemics. The first true known pandemics, which had wide geographical and social scale and intensity, are recorded for the Roman Empire. The Antonine Plague of the mid 160s CE during the reign of Emperor Marcus Aurelius, is believed to have been brought back by Roman troops after campaigns in the East. Once brought to the heart of the Roman Empire, this plague spread widely within the relatively unimpeded physical space of the Imperium. It was severe but not catastrophic: Harper believes that it left $90 \%$ of the Empire's population intact. Scholars speculate, though are not sure, that the disease involved was smallpox. ${ }^{12}$

The later Pestilence of Cyprian of the 270s CE was much worse in impact. Of uncertain type (speculations include measles, influenza or an Ebola-like syndrome), the outbreak began in Egypt, spread to Rome within the same year, and brought very high death and infection rates, though reliable data are lacking, as they are with most Ancient world events. There is some evidence to suggest that the episode weakened the Empire enough to cause its split into Eastern and Western halves in the 400s, though this development obviously has multiple origins. In both cases the wide spread of disease was facilitated by the presence of a large unified political jurisdiction with big cities (for the time), regular internal and external trade routes and relationships, agricultural estates and a large standing army. War was the proximate spark in the Antonine pandemic, though apparently not in Cyprian case whose cause is more obscure. ${ }^{13}$

And then there was the first known "Black Death" (Bubonic Plague) outbreak, the famous Plague of Justinian, first occurring in 541 and then returning in eighteen waves until 750. Though there are a few scholars that dispute that this was a plague pandemic, there is little doubt of its spread and destructiveness. Likely originating in Africa, the pestilence hit the Byzantine Empire, the Islamic world, and southwestern Europe rather than northern

Diseases: Past, Present and Future." Philosophical Transactions of the Royal Society of London. Series B: Biological Sciences 359 (2004), no. .1447: 1049-1058.

${ }^{11}$ Sheldon WatTs, Epidemics and History (New Haven: Yale University Press, 1997).

${ }^{12}$ Kyle Harper, The Fate of Rome: Climate, Disease and the End of an Empire (Princeton: Princeton University Press, 2017).

${ }^{13}$ Ibid. 
Europe. Estimates of $20 \%$ to $30 \%$ population losses during the first wave have been offered, admittedly on very fragmentary evidence. Probably spread mostly by trade activity, mortality and morbidity may have reduced trade by as much as two-thirds. ${ }^{14}$

\section{THE APOTHEOSIS}

OF THE SCIENTIFIC DISEASE MODEL

Of course, many more pandemics were to come, including the legendary Black Death in 1347-1352. But a major transformation was brought about by the Industrial Revolution, which intensified urbanisation and global trade and exchange, and brought with it new and more efficient disease transmission mechanisms such as factories, compulsory state-provided primary education and its crowded indoor classrooms, the railroad, and vast increases in dirt and pollution in ever-more dense urban areas. The result was the outbreak of "sanitary" diseases caused by polluted water and squalid living conditions. Epidemics and pandemics, notably cholera, broke out across the world in the 1800 s, with severe outbreaks in Japan and England. ${ }^{15}$

The Industrial Revolution also brought major alterations in Western Civilisation. Philosophical Rationalism, Science, and Materialism were already ascendant, but their triumph became complete by the end of the nineteenth century. Both practical engineering invention (during the First Industrial Revolution) and then scientific method and large-scale scientific enterprise (during the Second Industrial Revolution) radically transformed the ability to extract inputs and convert them to material output, triggering a complex social reorganisation which focused on delivering sufficient quality and quantity of labour, to service the growing industrial sector with its increasing political power.

"Progress" was now the secular faith, defined in narrow terms of material output. Social schisms were rife, but a scientific paradigm that abstracted away from and reduced them to technical issues with technical solutions became part of the elite narrative. In some ways all this was hard to argue with as the material results, narrowly defined, were quite impressive.

\footnotetext{
${ }^{14}$ Dionysios Stathakopoulos, Famine and Pestilence in the Late Roman and Early Byzantine Empire (Aldershot: Ashgate, 2004).

${ }^{15}$ Norman Longmate, King Cholera: The Biography of a Disease (London: Hamish Hamilton, 1966).
} 
Nowhere was this clearer than with advances in microbial knowledge. Robert Koch's pathbreaking 1876 publication on anthrax was followed by an explosion of microbiological knowledge that produced innovations such as passive immunotherapies, vaccines, and antimicrobials. ${ }^{16}$ Meanwhile the socalled "public health revolution" was rolling out across the industrialising world, refining and rapidly implementing and disseminating effective sanitary improvements in burgeoning cities, reducing their role as traditional vectors of disease. ${ }^{17}$ Both developments suggested that "disease" was a purely technical problem, with solutions both "high-tech" (e.g. vaccines) and "low-tech" (e.g. urban sewerage and clean water systems). When these solutions were applied (and they were applied unevenly), the results seemed to speak for themselves. It seemed only a matter of time before disease could be conquered by science - along with every other human ailment, social and otherwise.

\section{GLOBALISATION \\ AND THE CONUNDRUMS OF DISEASE}

However, what the one hand was giving, the other was taking away, a process largely invisible to the technical and social elites of the time. The substantial environmental degradation caused by nineteenth century industrialisation was causing the very health problems that modern science and invention were simultaneously solving. Infectious disease outbreaks were intensified in Europe by the poor hygienic conditions of packed cities. Outside Europe a wave of ruthless western imperialism and increasingly intensive and unfettered trade (referred to in the dominant British ideology of the time as "free trade") provided excellent conditions for carrying human illnesses far and wide. Mass migration, famines and malnutrition induced by colonialism weakened population resistance, and resource extraction created ecosystem conditions amenable to the propagation of infection, zoonotic and otherwise. Non-European subjugated populations were well aware of these conditions since they were living under them; but their European masters were officially indifferent, supported by racist ideologies at both elite and

\footnotetext{
${ }^{16}$ Steve M. Blevins and Michael S. BronZe, "Robert Koch and the 'Golden Age' of Bacteriology," International Journal of Infectious Diseases 14 (2010), issue 9: e744-e751.

${ }^{17}$ Christopher Hamlin and Pat Sidley. "Revolutions in Public Health: 1848, and 1998?," Bmj 317 (1998), no. 7158: 587-591.
} 
mass levels. Science and public health did contain and reverse these problems significantly, at least in Europe and Japan; but as time would tell, only temporarily. ${ }^{18}$

The Industrial Revolution has now intensified into "globalisation"a vast expansion in economic, cultural, sociological, political and technical interdependency between widely different regions, populations and societies. It is too much to say that we now have one global civilisation. But western modalities of thought and action have become dominant, at least as overlays, across most of the globe. Table 1 summarises the idealised attributes of the western approach.

Table 1. Idealised attributes of globalised Western "civilisation"

\begin{tabular}{|c|c|c|c|}
\hline Attribute & $19^{\text {th }}$ century "apotheosis" & $20^{\text {th }}$ century "turn" & $27^{\text {st }}$ century "tensions" \\
\hline Materialism & $\begin{array}{l}\text { "Progress" measured in } \\
\text { narrow economic terms }\end{array}$ & Consumerist Individualism & Conspiracy theories \\
\hline Technocracy & $\begin{array}{c}\text { Technical bureaucracy and } \\
\text { management; "system" } \\
\text { thinking }\end{array}$ & $\begin{array}{l}\text { Technical progress v technical } \\
\text { failures }\end{array}$ & $\begin{array}{c}\text { Distrust of expertise; politicisation of } \\
\text { technical roles }\end{array}$ \\
\hline Science & $\begin{array}{l}\text { Scientific method writ } \\
\text { large }\end{array}$ & $\begin{array}{l}\text { "Big Science" — government- } \\
\text { industry nexus; periodic expertise } \\
\text { failures }\end{array}$ & Scientism v Cynicism \\
\hline "Mass" sociality & Mass Production & Mass Consumption & Social media tribalism \\
\hline $\begin{array}{l}\text { Input/output } \\
\text { efficiency }\end{array}$ & $\begin{array}{l}\text { Scale and scope } \\
\text { economies }\end{array}$ & $\begin{array}{c}\text { Negative external and system } \\
\text { effects }\end{array}$ & Climate and physical system crisis \\
\hline "Abstract" authority & $\begin{array}{l}\text { Democratic states and } \\
\text { "neutral" public } \\
\text { administration }\end{array}$ & $\begin{array}{l}\text { Official ideology (Capitalism vs. } \\
\text { Communism) }\end{array}$ & $\begin{array}{l}\text { Resurgent nationalism, populism, } \\
\text { corporatism, }\end{array}$ \\
\hline Multilateralism & $\begin{array}{c}\text { Technical conventions } \\
\text { (e.g. Geneva); National } \\
\text { Empires }\end{array}$ & Hegemonic"World Order" & $\begin{array}{c}\text { Political and economic regionalism } \\
\text { and dis-integration }\end{array}$ \\
\hline
\end{tabular}

The table tells the following story. Western civilisation became increasingly subsumed under an economic-technical model of extraction and production. In the first phase (1800-1914 roughly) the social paradigm

\footnotetext{
${ }^{18}$ Mike Davis, Late Victorian Holocausts: El Niño Famines and the Making of the Third World (London \& Brooklyn, NY: Verso Books, 2002).
} 
became philosophically materialist, with social values defined in physical terms and measured as such. Science and technocracy became permanent fixtures of private and public governance, devoted to material efficiency obtained through huge economies of scale and scope in extracting inputs and converting them into outputs. Social authority, already primarily secular, became increasingly "abstract" rather than spiritual or organic (the latter being immeasurable in any case). Societal organising principles became reducible to descriptions of social and political processes (e.g. "liberal democracy" and "market capitalism"), while human socialisation was increasingly done on a mass institutional basis, e.g. through mandatory public schooling yielding mass literacy and thus the ability to consume the content of widely available and cheap newspapers and books. This unity became a truly global system.

Then came a set of critical "turns" during the twentieth century where these embedded attributes deepened, evolved and internally conflicted. In Elias terms, sociogenesis created an increasingly efficient and materialistic social order running into physical limits previously ignored, especially negative "externalities" where hidden social costs of private market activities became ever more pronounced, and overall scarcities of resources. Psychogenetically, mass production required mass consumption, with individuality and the human need for emotional meaning and identity increasingly sublimated by mass marketing campaigns into consumption activities and, later, "lifestyle" categories. As social chains grew longer and more complex, attenuation and self-contradiction set in, with the inner restraint needed to fit into mass systems conflicting with the stimulation of consumer appetites.

Meanwhile philosophical materialism effectively denied human sociality, positing a rigorous methodological atomism in which "society" reduces to the sum of its parts, through marketplace popularity and procedural majorities in elective and legislative processes. This was a gain in the sense of providing greater space for personal identity and political expression, but it made social coordination through appeal to "higher" motives (rather than base ones) increasingly difficult. For the Cold War period, official ideologies filled this gap, but these were negatively framed against a "bad" alternative, rather than positively motivated towards a higher good, except by saying the relevant status quo was the best of all possible worlds. (As an aside the Communist world turned Capitalist logic on its head, but in both cases organic social process was denied).

Science, though still the most powerful mode of physical change ever created, became socially discredited as the scientific establishment inevit- 
ably showed feet of clay. Innovations, such as the splitting of the atom, brought anxiety and potential world destruction in addition to material progress, while scientists themselves proved to be human after all, often promising one result and then delivering another.

\section{CORONAVIRUS AND THE PRESENT \\ WESTERN CIVILISATION}

Covid-19 is part of another set of historical "turns" to the course of Western Civilisation in the $21^{\text {st }}$ century.

"Science", which claims to be neutral about spiritual and immaterial things, devoted to the control of physical cause and effect, certainly has exhibited proficiency there but inevitably has confronted the fact that even purely material dynamics of existence are too subtle to capture and control through logical methods and scientific means.

With respect to disease, prodigious progress has been made on the pharmaceutical front, and some illnesses, such as polio and smallpox, have been truly eradicated. But optimism that all disease could be eliminated is now gone. Scientists still tend to use a "battle" metaphor in which the superior ability of microbes to adapt to new ecologic opportunities through rapid replication and genetic change (such as mutation), is matched, though not trumped, by human ingenuity and creativity. To put it another way, human beings can be said to have a cultural advantage over the purely biological advantages of microbes. However, while microbes have no culture, human beings still are part of biology. To "battle" microbes is to battle a part of oneself.

In fact, the microbe world does not follow Newtonian laws. Influenza, for example, is said to exist on the edge of what geneticists call "error catastrophe", mutating so promiscuously and rapidly that its genome teeters on the brink of dysfunctionality. ${ }^{19}$ Covid-19 seems to be similar in this way. This "chaotic" genetic quality is what allows many microbes to be able to mutate and adapt to new hosts and transcend species barriers so efficiently.

This complex and constant feedback loop (perhaps enmeshment might be a more accurate word) between human society and nonhuman ecosystem is one that our mental models cannot fathom. These models are based on opti-

\footnotetext{
${ }^{19}$ Jesse Summers and Samuel Litwin, "Examining the Theory of Error Catastrophe," Journal of Virology 80 (2006), no. 1: 20-6.
} 
mising a "stable system equilibrium" that arguably does not exist in the "natural world". This paradigm is however at the heart of technocratic and scientific endeavour, and while it is a useful fiction that enables the structuring of targeted inquiry yielding narrow but tangible results, including vaccines, true mastery of physical reality remains impossible.

Simultaneously the exclusive materialism of the Western philosophical outlook (lip service to other dimensions notwithstanding), limits a collective ability to deal with the timeless immaterial dimensions of mass disease. No one would want to return to the Black Death with its uncontrolled mortality, morbidity and outbreaks of communal violence and superstition. But we may be prone to our own technologised versions of some of these things. The immaterial dimensions of reality are left entirely out of the scientific and technical paradigm, leaving a vacuum to be filled by mechanistic approaches that can be culturally problematic.

Doctors distinguish between the subjective experience of sickness, called "illness" and "disease", referring to an objective physiological dysfunction. ${ }^{20}$ As a disease Covid-19's highly variable and unpredictable behaviour is challenging enough. As an illness, the individual and collective emotional, psychological and, dare one say it, spiritual experiences of those afflicted, recovering, and in relationship to a sufferer cannot be easily held anywhere in the current society. Civilisation has a core function of meeting the immaterial needs of humanity. But these have been left unattended by the establishment mainstreams. Religion and community were traditional containers, but both are now greatly weakened and fragmented, tending to be channelled into the echo chambers of mass and social media, meaning dissipating rather than joining up there. Secular religions (including "scientism"), conspiracy theories, quackery, evangelical and charismatic Christian sects, and cults of various flavours fill the vacuum in rather chaotic fashion as a sort of sociological "error catastrophe" of its own.

Meanwhile, cognition of the objective phenomenon of Covid-19 even by qualified elites is impaired. Beyond an only partially fathomable virology, and a cynical attitude towards expertise, the study of disease is now more than ever a truly inter-/multi-/pan-/trans-disciplinary affair that spans the subjective and objective, the material and immaterial. The modern technical bias has rather completely fragmented empirical and theoretical investigation into ghettoised and competing camps that can have trouble even talking to one another, not necessarily out of disdain (though that can be there), but out of

\footnotetext{
${ }^{20}$ PorTa (ed.), A Dictionary of Epidemiology.
} 
lack of capacity and time and incentive to do so, even in public health which is more interdisciplinary than many other fields.

The scientific/technocratic civilisation thus may be rendering Covid-19 less deadly and widespread than it would have been otherwise, since we do have workable models of its aetiology and good knowledge, based on past experience, of how to limit transmission and treat outbreaks both individually and collectively. We also have good protocols for observing and responding to its evolution in real-time. But our social response to this syndrome (and others that will likely follow it) is arguably enfeebled.

Materialism combined with Covid-19 has thus created a social paradox: a narrow hyper-individualism based largely on leisure and work choices, enshrined in a market metaphor that equates the sum of individual purchases of commodities at different price levels to social choice regarding life's important collective dilemmas, set against the need for voluntary social coordination for higher public purpose based on long-term individual sacrifice.

It is not necessarily the case that people are now more clinically "narcissistic", nor is the current order an entirely "bad" thing. In Elias's terms, it is simply that we have created a society based on mechanistic means to achieve mechanistic ends, while human beings, and all other living creatures, remain organic in their fundamentals. Sociogenesis in a "systems" based civilisation has led to a psychogenesis in human "individuality" where "individuation" now allows a wide license in "individualistic" arenas as compensation for the human conformity required to meet the demands of the machines the system runs on.

This can be most clearly seen at the elite level, where leaders uncomfortably straddle a bifurcated value system. On the one hand short-term social and individual compromises through collective shutdowns and restrictions are promoted based on public health advice. But this is in constant tension with calls to "balance" restrictions on our "lifestyles" and "livelihoods" (code word for work and consumption) against "freedom" and a return to "normalcy" (code words for personal license and the status quo).

Certainly, there is some cynical political manipulation present as particular economic interests and ideological advocates try to cut their monetary losses. But there is also a true statement of a current cultural conundrum. As but one example, Australian Treasurer Josh Frydenberg said recently, in continuing to follow a viral suppression rather than elimination strategy: "Treasury ... suggests a six-week Australia-wide hard lock down could re- 
duce GDP by around $\$ 50$ billion. This is what is at stake. ${ }^{21}$ The point is not illegitimate but what appears to matter most is the narrow definition of economic output. One has trouble imagining Winston Churchill saying something like this to the English people during World War 2.

At the mass level, such mixed messages breed understandable confusion. Should we wear masks, maintain physical distancing, and stay home, or not? One can be forgiven for not being sure as the message changes week to week, and not simply because of the uncertain progress of the virus. The cynicism about expertise does not help certainly. But fundamentally, the average person now is closely identified with work and consumption activities as a point of identity and meaning. Recommended protocols for isolation are unnatural in an animal sense which is why following them requires cultural strength, a strength that is now greatly weakened.

Instead of culturally sanctioned social coordination, we default to technological methods of social direction. There are now many more methods to track, contain and treat pandemics than ever before. At the same time, these can be tools of oppression, intimidation and social evisceration, even as they may be protecting lives.

This is not a new situation, to be sure. State policies regarding cholera, for example, often discriminated against disadvantaged groups during suppression efforts. But just as modern society has created conditions for more efficient transmission of disease, it has also allowed for more efficient mechanised social control. This has already become a touchstone of technologised society in other areas, e.g. mass surveillance by public-private security apparatuses. How much this will become an even more pervasive permanent feature of society remains to be seen.

At the same time, social isolation is also more technologically enabled than ever. Cashless transactions, automation, automobility (as opposed to common carriage such as public transport), remote work, remote surveillance, care delivery via robot - all these enable lessening of direct human contact and the need for provision of collective space (e.g. libraries, theatres, offices etc). Social overhead costs will now likely be further offloaded onto citizens and employees along with the increasingly insecure work of the socalled "gig economy."

To round out the paradoxes, this first "jet age" pandemic has revealed the double edge hidden inside efficiency in movement and travel. Border clo-

\footnotetext{
${ }^{21}$ Katie Burgess, "National Cabinet Rejects Elimination Strategy," Canberra Times, July 24, 2020.
} 
sures, once anathema to internationalists, have become a standard tool in combatting Covid's spread. Globalisation was already fraying but the pandemic may end up reversing it somewhat.

Once again, these changes are not all bad or good, economically or socially. But greater technologisation of work and social organisation will likely result in continued social evisceration in the name of greater mechanical "functionality."

One final issue that should be noted is economic inequality. This is certainly nothing new in human history. But in pre-industrial pandemics, elites and common people were both at relatively high risk. Elites could certainly always take more palliative measures than the poor, such as escaping to walled castles. But the Black Death, as but one example, took both commoners and nobles at prodigious rates. The Industrial Revolution began a process by which it became more and more feasible to technologically separate oneself from larger social conditions, if having access to great enough wealth. A greater understanding of disease aetiology and prevention allows the very rich to now employ ever more sophisticated methods of isolating themselves from contagion. This has added an instability to the social consensus needed to pull together and respond to pandemic generally.

\section{POSSIBLE FUTURE PATHS}

It has been argued that the Renaissance and the Enlightenment, which emerged on the heels of the Black Death, owed its birth to the intellectual upheavals and questions raised by the epidemic and its successive waves. Thus began an evolution of Western Civilisation to the current technocratic and materialist version we have now. Will Covid-19 lead to a similar major paradigm shift?

It does seem likely because this pandemic is pushing against so many cultural challenge points that have existed for a long time. Just as the Russian Revolution came out of a weakening Romanov dynasty pushed to the brink by a World War, the current globalised (though fragmenting) version of capitalist society has been weakened in many ways, socially, economically, even materially, and this episode is certainly exposing and pushing these challenges further. It may or may not lead to a systemic disruption or break, but fundamental change seems inevitable.

What kind of change will it be? A standard narrative being offered now is based on the Enlightenment ideal. Frank Snowden, a noted scholar of the 
history of epidemic and pandemic, has argued that Covid-19 can push us towards greater unity, social purpose and rational self-interest, or towards the darkness of a neo-barbarism. ${ }^{22}$ This is a variation on a modern theme expressed by many apologists for the existing order such as Stephen Pinker who adhere to a "better angels" ideal in which science, rationality, and innovation are set against the more primal instincts of "primitive man" with the former prevailing. ${ }^{23}$ Freud held a similar, though more pessimistic, Manichean view.

However, this represents a limited view of social evolution. Human society and psychology are not, it has been argued here, immutable, but highly changeable, likely to go ahead, back and in entirely new directions all at the same time. Indeed Elias, in later work, posited that "technization" - the ability of humanity to exploit "lifeless" resources for material gain - is a parallel to the "civilising process", both "involuntary", in the sense of being natural but unconscious (like biological evolution) with the former being an increasingly prominent feature of modern scientific society. ${ }^{24}$

The "better case" scenario is that we invite back in the immaterial in some meaningful and collective (though not authoritarian) sense with technology and science becoming means to higher social ends (again, without being oppressive). Here technization will become subordinate to cilivisation, with human growth, very broadly defined, becoming the paramount imperative.

One "poorer case" scenario is that we attain a sort of sub-optimum (to use the technocrat's terms) in which bureaucratic technical control is used to manage society by tracking and keeping individuals in their places for disease control purposes, allowing for degrees of individual autonomy in work, residential, travel, and consumption choices, varying according to the preferences of the State and its private operatives, fluctuating according to the political interpretations of public health expertise. This seems to be the current trajectory of most national Covid-19 responses to varying degrees. Temporary and preliminary right now, this may well harden into a permanent and dysfunctional order. Here technization dominates and distorts civilisation.

There is, of course, a "worst case" scenario where we devolve into a social jungle amidst the ruins of a modern society. In this case humans devolve

\footnotetext{
${ }^{22}$ Frank Snowden, Epidemics and Society: From the Black Death to the Present (New Haven, CT: Yale University Press, 2019.

${ }^{23}$ Steven PInKER, The Better Angels of Our Nature: Why Violence Has Declined (New York, Penguin Group USA, 2012).

${ }^{24}$ Norbert ELIAS, "Technization and Civilization," Theory, Culture \& Society 12 (1995), no. 3: 7-42.
} 
back into "primitive" social forms with perhaps remnants of technologised brutality added. In this case both technization and civilisation deform and regress.

Which one is most likely? Certainly the actual outcomes will be far more subtle than these three idealised scenarios. Unless societal consciousness is raised somehow, however, the future does not look particularly promising.

\section{BIBLIOGRAPHY}

BARnes, Ethne. Diseases and Human Evolution. Albuquerque: University of New Mexico Press, 2005.

Blevins, Steve M., and Michael S. BronZe. "Robert Koch and the 'Golden Age' of Bacteriology." International Journal of Infectious Diseases 14 (2010), issue 9: e744-e751. DOI: https:// doi.org/10.1016/j.ijid.2009.12.003.

Burgess, Katie. "National Cabinet rejects elimination strategy." Canberra Times. July 24, 2020

Collinge, Sharon, and Chris Ray. Disease Ecology: Community Structure and Pathogen Dynamics. Oxford: Oxford University Press, 2006.

DAvis, Mike. Late Victorian Holocausts: El Niño Famines and the Making of the Third World. London \& Brooklyn, NY: Verso Books, 2002.

DuBos, René Jules. Mirage of Health: Utopias, Progress and Biological Change. New Brunswick, NJ: Rutgers University Press, 1987.

Elias, Norbert. "Technization and Civilization.” Theory, Culture \& Society 12 (1995), issue 3 : 7-42. DOI: https://doi.org/10.1177/026327695012003002

EuIAs, Norbert. The Civilizing Process. Sociogenetic and Psychogenetic Investigations. Revised edition. Oxford: Blackwell, 2000.

Freud, Sigmund. Civilization and its Discontents. Translated by James Strachey. Peterborough: Broadview Press, 2015.

Hamlin, Christopher, and Pat SidLey. "Revolutions in public health: 1848, and 1998?" Bmj 317 (1998), no. 7158: 587-591.DOI: https://doi.org/10.1136/bmj.317.7158.587.

Harper, Kyle. The Fate of Rome: Climate, Disease and the End of an Empire. Princeton: Princeton University Press, 2017.

Huntington, Samuel. “The Clash of Civilizations?” Foreign Affairs 72.3 (Summer, 1993): 22-49.

Karlen, Arno. Plague's Progress: A Social History of Disease. London: Gollancz, 1995.

Longmate, Norman. King Cholera: The Biography of a Disease. London: Hamish Hamilton, 1966.

McMichael, Anthony J. "Environmental and Social Influences on Emerging Infectious Diseases: Past, Present and Future." Philosophical Transactions of the Royal Society of London. Series B: Biological Sciences 359 (2004), no. 1447: 1049-1058.

PINKER, Steven. The Better Angels of Our Nature: Why Violence has Declined. New York: Penguin Group USA, 2012.

Porta, Miquel (ed.). A Dictionary of Epidemiology (5 $5^{\text {th }}$ edition). Oxford: Oxford University Press, 2009. 
Snowden, Frank. Epidemics and Society: From the Black Death to the Present. New Haven, CT: Yale University Press, 2019.

Stathakopoulos, Dionysios. Famine and Pestilence in the Late Roman and Early Byzantine Empire. Aldershot: Ashgate, 2004.

Summers, Jesse, and Samuel Litwin. "Examining the Theory of Error Catastrophe." Journal of Virology 80 (2006), no 1: 20-6. DOI: 10.1128/JVI.80.1.20-26.2006

Torrey, E. Fuller, and Robert H. Yolken. Beasts of the Earth: Animals, Humans and Disease. New Brunswick, NJ: Rutgers University Press, 2005.

WATTS, Sheldon. Epidemics and History. New Haven, CT: Yale University Press, 1997.

\section{COVID-19 AND THE FUTURE OF WESTERN CIVILISATION}

\section{S u m m ary}

Civilisation is in many ways the apotheosis of the human social impulse, good and bad, and, whatever happens, the Age of Coronavirus is going to shape the western version of this shared culture profoundly. This article reviews the way in which human sociality has shaped human disease and vice-versa and offers three idealised possible futures for Western Civilisation that Covid-19 might produce.

Key words: Covid-19; coronavirus; Western Civilisation; sociality; disease.

\section{COVID-19 A PRZYSZŁOŚĆ CYWILIZACJI ZACHODNIEJ}

\section{Streszczenie}

Cywilizacja jest pod wieloma względami apoteozą ludzkiego impulsu społecznego, dobrego i złego, a cokolwiek się stanie, era koronawirusa głęboko ukształtuje zachodnią wersję tej wspólnej kultury. W artykule omówiono sposób, w jaki społeczność ludzka ukształtowała ludzkie choroby i vice versa, a także przedstawia trzy wyidealizowane możliwe wersje przyszłości cywilizacji zachodniej, które mogą być efektem Covid-19.

Słowa kluczowe: Covid-19; koronawirus; cywilizacja zachodnia; socjalność; choroba. 